\title{
REPRESENTASI HEGEMONI KINERJA POLRI DALAM PEMBERITAAN TEROR AIR KERAS NOVEL BASWEDAN DI KOMPAS.COM
}

\author{
Dina Etikawati \\ Universitas Diponegoro \\ email: dinaetikawati28@gmail.com
}

\begin{abstract}
Abstrak
Berdasarkan analisis bahasa fungsional, pemakaian unsurgramatikal menggambarkan realitas sosial yang ada. Penelitian ini bertujuan untuk mendeskripsikan representasi kinerja kepolisian tentang kasus teror air keras Novel Baswedan dan upaya hegemoni dalam pemberitaan di kompas.com. Penelitian ini menerapkan pedekatan analisis wacana kritis model Fairclough. Data penelitian menggunakan pernyataan langsung kepolisian dalam pemberitaan di kompas.com. Data dikumpulkan dari edisi Mei 2017 s/d Desember 2019 yang diseleksi berdasarkan konteks penyelidikan kasus teror air keras Novel Baswedan. Penelitian ini menggunakan total 42 kutipan pernyataan langsung dari 18 teks berita yang dianalisis menggunakan metode abduktif inferen. Hasil penelitian sebagai berikut. Pertama, lembaga kepolisian diinterpretasikan memiliki kinerja sebagai berikut, bertanggungjawab yang direpresentasikan temuan proses material 39\%, berkredibilitas direpresentasikan proses mental 30\% dan proses verbal 14\%, dan lembaga kooperatif direpresentasikan proses relasional 13\% dan proses behavioral $4 \%$. Kedua, pernyataan langsung Polri juga berfungsi sebagai upaya menghegemoni seperti, meyakinkan, mempengaruhi, dan mengontrol pihak lain.
\end{abstract}

Kata kunci: representasi, kinerja, hegemoni

\section{THE REPRESENTATION OF POLRI PERFORMANCE HEGEMONY IN NOVEL BASWEDAN ACID ATTACK NEWS ON KOMPAS.COM}

\begin{abstract}
Based on the analysis of functional language, the use of grammatical elements illustrates the existing social reality.This study aims to describe the representation of the police's performance in ivestigating the case of Novel Baswedan acid attack and the hegemony efforts in reporting in Kompas.com. This study applies the approach of analysis of Fairclough's critical discourse. The research data were taken from the police's direct statement in the news in Kompas.com. The data were collected from the May 2017 tothe December 2019 editions and were selected based on the context of the investigation of Novel Baswedan's acid attack. This study used a total of 42 direct statement excerpts from 18 news that were analyzed using inferent abductive methods. The research results are as follows. First, the police institution is interpreted to have responsible performance that is represented by the findings of the material process of 39\%; credibility is represented
\end{abstract}


by mental processes of $30 \%$ and verbal processes of $14 \%$; and the cooperative institutions represent a relational process of $13 \%$ and behavioral processes of $4 \%$. Second, The Police's direct statement also functions as an attempt to hegemony such as, convincing, influencing, and controlling other parties.

Keywords: representation, performance, hegemony

\section{PENDAHULUAN}

Analisis wacana kritis memiliki pandangan bahwa bahasa merupakan bagian dari sebuah peristiwa sosial. Fairclough (2001), mengemukakan bahwa bahasa merupakan bentuk dari praktik sosial yang berhubungan dengan kekuasaan dan kekuatan. Sehubungan dengan itu, bahasa tidak sekadar dianalisis berdasarkan tata bahasa dan sintaksis dalam sudut pandang analisis wacana kritis. Akan tetapi, analisis bahasa akan dikaitkan dengan konteks sosial, dimana bahasa tersebut diproduksi. Hal itu terbukti pada data penelitian Mardikantoro (2014), mengemukakan bahwa bahasa tidak hanya sekadar alat penyampaian informasi kepada publik. Bahasa juga dapat digunakan untuk suatu tujuan tertentu termasuk praktik kekuasaan, jikalau dihubungkan dengan konteks yang menyertai.

Pemikiran bahasa dapat menjadi sarana guna praktik sebuah kekuasaan dikemukakan (Gramsci, 1971). Dalam pendapatnya, Gramsci (19971: 32), mengemukakan bahwa sebuah upaya dominasi kekuasaan dan kekuatan dapat dilakukan tidak hanya dengan senjata, tetapi juga dengan penerimaan publik. Penerimaan publik merupakan tujuan dari dominasi kelompok kelas sosial tinggi terhadap kelompok kelas sosial di bawahnya. Upaya dominasi tersebut dapat tercapai dengan penggunaan tata bahasa dan sintaksis tertentu dalam sebuah wacana. Hal itu senada dengan temuan Abdi, Nurhadi, dan Imam (2016), bahasa dapat digunakan untuk menciptakan sebuah kekuasaan sehingga bahasa memiliki kontrol terhadap orang lain untuk bertindak sesuai yang dikehendaki.

Peranan bahasa yang membentuk wacana dalam upaya dominasi juga diutarakan oleh Fairclough (1995: 94), bahwa aplikasi hegemoni menyiratkan adanya perkembangan dalam berbagai aspek di masyarakat, seperti pekerjaan dan pendidikan, dari praktik-praktik yang menaturilisasi hubungan dan ideologi tertentu. Praktik-praktik yang dilakukan secara naturalisasi tersebut bersifat diskursif. Oleh sebab itu, konvensi yang dilakukan akan ditangkap dengan masuk akal. Di dalam proses naturilisasi wacana tersebut, bahasa menjadi salah satu kunci keberhasilan upaya hegemoni. Hal itu mempertegas bahwa terdapat hubungan ganda antara wacana dengan hegemoni. Pertama, praktik hegemoni dan upaya hegemoni menggunakan bentuk praktik diskursif dalam interaksi secara tertulis ataupun lisan. Kedua, wacana masuk ke dalam lingkup hegemoni budaya.

Berdasarkan pemikiran tentang adanya hubungan wacana dengan 
hegemoni, dapat disimpulkan bahwa pendekatan analisis wacana kritis dan teori hegemoni bisa dipadukan untuk menganalisis sebuah teks. Van Dijk (1998), berpendapat bahwa analisis wacana kritis adalah sebuah bidang studi yang mempelajari dan mengkaji teks dan ujaran untuk mengungkap sumber diskursif dari kekuasaan, dominasi, ketidaksetaraan, dan bias. Pandangan tersebut serupa dengan Fairclough (1995), menyatakan analisi wacana kritis bertujuan untuk menganalisis secara sistematis hubungan yang bias dari kausatif dan determinasi antara (a) praktik diskursif, peristiwa, dan teks, dan (b) sturktur sosial dan budaya, relasi, dan proses dalam cakupan luas. Definisi lain mengenai konsep analisis wacan kritis dapat merujuk kepada pendapat Gee (1999), Wodak (1996), dan lainnya.

Penelitian analisis pernyataan langsung kepolisian mengenai penyiraman air keras terhadap Novel Baswedan menggunakan wacana kritis Fairclough. Fairclough (2001: 21), membagi analisis wacana kritis menjadi tiga dimenc4si, (a) deskripsi, tahap yang berkaitan dengan teks sebagai properti utama; (b) interpretasi, tahap yang fokus analisis hubungan antara teks dan interkasi; dan (c) eksplanasi, tahap akhir fokus pada analisis hubungan antara interasi dengan konteks sosial. Ketiga tahapan tersebut tidak berdiri sendiri. Akan tetapi, proses analisis saling bertautan antara hubugan teks, proses, dan konteks sosial yang menyertai.

Konsep model analisis wacana kritis Fairclough (2001) memiliki keterkaitan dengan studi sistemik fungsional linguistik Halliday. Keterkaitan tersebut ada di pemikiran yang sama bahwa bahasa dalam wujudnya sebagai teks merupakan sebagai praktik sosial. Teks merupakan sebuah produk dan wacana berisi semua proses interaksi sosial yang terepresentasi melalui unsur linguistik di dalam teks. Unsur- unsur linguistik tersebut dapat dianalisis secara terperinci untuk mengungkap hal yang tersirat. Pemikiran tentang teks tersebut serupa dengan pandangan Halliday dan Matthiessen (2004: 29), bahasa memiliki tiga metafungsi, a) fungsi ideasional, b) fungsi interpersonal, dan c) fungsi tekstual. Unsur linguistik yang membentuk teks merupakan representasi dari pengalaman dan pengetahuan yang dimiliki penutur. Oleh sebab itu, pada tahap interpretasi wacana Fairclough, unsur linguistik dari teks dapat dikaji dengan penerapan sistemik fungsional Halliday. Sistemik fungsional linguistik Halliday memiliki beberapa teori untuk mengkaji teks, salah satunya transitivitas yang terdiri atas proses, partisipan, dan sirkumstan.

Transitivitas merupakan sistem untuk menafsirkan pengalaman penutur sebagai bagian jenis proses yang melibatka partisipan dan sirkumstan (Halliday dan Matthiessen (2004:170). Pemikiran tersebut selaras dengan Yuliana, Manda, dan Kamsinah (2018), bahwa transitivitas bisa memperlihatkan bagaimana manusia mendeskripsikan pengalaman berdasarkan keadaan sekitar yang menyertai. Pengamalan, ide, serta rencana yang dimiliki oleh penutur akan suatu hal dapat tergambar dari bahasa yang digunakan. Dan, pada momen tersebut transitivitas berperan sebagai alat pengurai hal yang tersimpang lewat bahasa. Hal itu juga termuat dalam data penelitian 
Kusumawardani dan I Ketut (2020), tentang praktik berbahasa pada teks pidato pelantikan Presiden Joko Widodo yang sarat visi-misi kepala Negara.

Proses terbagi ke dalam lima tipe, yaitu proses material, proses mental, proses behavioral, proses verbal, dan proses relasional. Gerot dan Wignell (1995:55), menjelaskan bahwa proses material menggambarkan ekspresi yang dilakukan oleh suatu entitas fisik. Proses material yakni suatu proses yang melakukan sebuah tindakan. Tindakan tersebut dilakukan oleh actor dan tidakan yang dikenai disebet goal. Proses mental berkaitan dengan indera perasa berupa merasakan, berpikir, dan persepsi terhadap suatu hal. Pandangan tersebut dikutip oleh Wiratno (2018: 94), bahwa beberapa penanda Bahasa Indonesia proses mental mengenai persepi, di antaranya melihat, mendengar, dan merasa; afeksi meliputi takut, suka, dan khawatir; kognisi meliputi berpikir, mengerti, dan membayangkan; dan keinginan misal berharap. Partisipan proses mental meliputi senser dan phenomenon. Halliday dan Mattiessen (2004: 182), menjelaskan proses verbal merupakan tipe proses hubungan secara simbolik yang dilakukan atas kesadaran manusia dengan penanda bahasa. Proses verbal memiliki tiga partisian, yaitu target reciever, verbiage, dan receiver. Tipe proses terakhir yakni proses relasional, dimana klausa digunakan untuk mengkasifikasi dan identifikasi suatu hal. Secara rinci penerapan sistem transtivitas dapat dirujuk dalam Eggins (1994), Gerot dan Wignell (1995), dan Halliday dan Matthiessen (2004).

Unsur linguistik dalam wacana dapat dikaji berdasarkan sistemik fungsional linguistik. Proses tersebut jika diselaraskan dengan tahap analisis wacana kritis Fairclough maka berada di tahap deksripsi. Pada tahap deskripsi unsur-unsur lingusitik yang hadir akan dikaji agar mendapatkan hasil representasi penggambaran pengalaman dari makhluk hidup terhadap kondisi sekitarnya. Tahap interpretasi mengekspolarasi hubungan antara teks dengan 'apa' yang diinterpretasikan. Proses tersebut melibatkan dasar pengetahuan ( members' resources) sebagai pentu hasil yang diperoleh interpreter (Fairclough, 2001: 118). Peran hegemoni Gramsci dalam tahap analsis ini akan diperlukan pada tahapan eksplanasi. Aspek praktik sosiokultural ada dalam tahap ekspalanasi, yakni tahapan yang bertujuan menggambarkan bahwa wacana sebagai bagian dari proses sosiadan berperan sebagai praksis sosial. Dan juga, bagaimana struktur sosial membentuk members' resource yang berdampak terbentuknya wacana, dimana nanti wacana berpengaruh tersebut terhadap pemertahanan atau perubahan MR sehingga dapat menyebakan terjadi permertahan atau perubahan struktur sosial. Keberadaan hegemoni yang tersirat dalam teks dapat terlihat di tahap eksplanasi. Hal itu ditegaskan oleh Fairclough (1995: 2), teori hegemoni Gramsci berada di dalam analisis dari praksis sosiokultural.

Berdasarkan uraian di atas, dapat disimpulkan bahwa bahasa memiliki peran yang lebih besar, disamping menjadi alat komunikasi dan pertukaran informasi lisan maupun tulis. Bahasa dapat menjadi pengungkap ide, pemikiran, dan rasa antar satu pihak 
dengan yang lain. Oleh sebab itu, bahasa dapat menjadi suatu hal yang penting dalam membongkar realitas tersembunyi antara teks dan konteks. Fenomena peran strategis bahasa sebagai media komunikasi juga terjadi dalam pernyataan-pernyataan langsung kepolisian tentang kasus penyerangan air keras Novel Baswedan. Pernyataanpernyataan kepolisian yang dimuat oleh media dapat memberikan efek lebih selain bentuk penyampaian informasi kepada masyarakat. Efek lain itu dapat muncul, karena media memiliki kekuatan untuk menghegemoni didukung dengan narasi dan hasil wawancara narasumber. Hal itu dibuktikan dalam penelitian Hasan dan Ali (2017), bahwa pemberitaan media dapat menjadi konstruksi dari sebuah realitas suatu peristiwa sehingga membentuk wacana.

Peristiwa yang menimpa Novel memimbulkan pemberitaan dari berbagai sudut pandang. Salah satu sudut pandang pemberitaan yakni waktu yang diperlukan kepolisian untuk mengungkap pelaku dan motif. Waktu yang tergolong relatif lama, berkisar hampir 3 tahun, menimbulkan beberapa asumsi di publik. Asumsi tersebut muncul dari beberapa pihak, di antaranya Novel Baswedan, Danhil Anzar (Ketua PP Muhammadiyah), dan Fadli Zon. Salah satu pernyataan tersebut berasal dari pihak korban yang dirilis oleh majalah Time edisi 13 Juni 2017. Di dalam sesi wawancara dengan Time, Novel memberikan pernyataan bahwa Novel mendapatkan informasi mengenai kemungkinan keterlibatan oknum kepolisian dalam kasus penyerangannya. Pernyataan yang dirilis dalam majalah tersebut menjadi pematik munculnya keraguan di publik terhadap kinerja Polri terkait kasus ini. Kepolisian juga memberikan respon terhadap informasi yang berkebang melalui media.

Pernyataan kepolisian tentang proses investigasi kasus penyerangan Novel dalam pemberitaan kompas.com merupakan salah satu bentuk wacana. Penggunaan bahasa dalam wacana tersebut memiliki kekuatan yang dapat berdampak terhadap publik. Bahasa memiliki fungsi bukan hanya sebatas alat komunikasi atau pengetahuan, tetapi juga sebagai alat untuk kekuasaan (hegemoni). Pemikiran itu dilandaskan pada realita bahwa dalam berkomunikasi, penutur akan upaya untuk dipatuhi, dihormati, dan dipercaya selain dipahami. Penutur dalam konteks penelitian ini yaitu kepolisian sebagai lembaga hukum berwenang dalam menegakkan keadilan dan kebenaran. Kepolisian memiliki daya untuk memungkinkan upaya hegemoni melalui wacana tersebut.

Penelitian ini berbeda dengan referensi penelitian terdahulu, yakni penggunaan transitivitas sebagai alat untuk membongkar upaya hegemoni dengan berlandasankan analisis wacana kritis. Fokus dalam kajian ini yakni upaya hegemoni pihak kepolisian terkait proses investigasi kasus penyerangan terhadap Novel Baswedan. Upaya tersebut diduga guna menetralisir beberapa asumsi negatif yang muncul di publik. Penelitian ini akan menjabarkan representasi bentuk kinerja yang telah dilakukan oleh pihak kepolisian dan bagaimana upaya hegemoni yang dilakan oleh kepolisian melalui pilihan diksinya. Tujuan yang 
ingin dicapai melalui permasalahan tersebut ialah, a) mendeskripsikan bentuk kinerja Polri yang terepresentasi melalui unsur linguistik dalam wacana, dan b) menjabarkan upaya hegemoni dalam pernyataan-pernyataan kepolisian.

Fokus dalam kajian ini yakni upaya hegemoni pihak kepolisian terkait proses investigasi kasus penyerangan terhadap Novel Baswedan. Upaya tersebut diduga guna menetralisir beberapa asumsi negatif yang muncul di publik. Penelitian ini akan menjabarkan representasi dari kinerja yang telah dilakukan oleh pihak kepolisian dan bagaimana upaya hegemoni yang dilakan oleh kepolisian melalui pilihan diksinya. Tujuan yang ingin dicapai melalui permasalahan tersebut ialah, a) mendeskripsikan kinerja Polri yang terepresentasi melalui unsur linguistik dalam wacana, dan b) menjabarkan fungsi dari wacana Polri dalam upaya untuk menghegemoni.

\section{METODE}

Penelitian ini merupakan penelitin yang bersifat kualitatif Moleong (2005:11). menjelaskan penelitian kualitatif memahami suatu fenomena pada subjek penelitian, seperti perilaku, persepsi, motivasi dan sebagainya secara keseluruhan kemudian dideskripsikan dalam bentuk kata-kata. Bersifat kualitatif, dikarenakan fenomena permasalahan dalam penelitian diungkapkan dalam bentuk pendeksripsian yang menggunakan kata-kata. Dan juga, diperkuat dengan pendekatan analisis wacana kritis model Fairclough (1995) yang melihat wacana sebagai teks sehingga dinilai dapat merepresentasikan pengalaman dan pemahaman pembuat teks. Oleh sebab itu, kajian ini akan melalui tahap deksripsi, interpretasi, dan eksplanasi guna menelisik representasi hegemoni kinerja kepolisian melalui pernyataan-pernyataan yang diproduksi.

Sumber data penelitian ialah teks berita mengenai peneroran air keras terhadap Novel Baswedan yang dimuat kompas.com. Teks berita yang digunakan yakni edisi dalam rentang waktu Mei 2017 sampai dengan Desember 2019. Data yang digunakan dalam penelitian yaitu unsur-unsur linguistik meliputi, kata , klausa, dan kalimat dari kutipan pernyataan-pernyataan pihak kepolisian. Kutipan pernyataan-pernyataan langsung kepolisian dalam teks berita merupakan transkrip hasil wawancara antara wartawan dan kepolisian. Data penelitian dikumpulkan dengan metode simak dan teknik catat. Sudaryanto (2015:206), menjelaskan bahwa metode simak dilakukan dengan menyimak penggunaan bahasa dalam bentuk lisan maupun tulis. Proses pengumpulan data dengan metode simak juga didukung teknik catat yang dilakukan dengan mencatat temuan kata, klausa, dan kalimat dalam kutipan pernyataan Polri. Temuan unsur-unsur linguistik tersebut dicatat dalam kartu data. Langkah pertama, peneliti menyimak teks berita kompas.com yang mengandung kutipan pernyataan Polri mengenai penyerangan air keras terhadap Novel Baswedan. Hal itu bertujuan untuk menemukan unsur linguistik dalam kutipan pernyataan langsung Polri tersebut. Kedua, temuan unsur linguistik berkaitan dengan permasalahan penelitian dicatat dalam kartu data.

Metode analisis data penelitian ini disesuaikan dengan perspektif analisis 
wacana kritis Fairclough (Faiclough, 1995) dan metode abduktif inferensi (Krippendorf, 2004). Fairclough (1995) membagi tiga tahapan analisis wacana kritis, yaitu deskripsi, interpretasi, dan eksplanasi. Tahap deskripsi, teks kutipan langsung pernyataan Polri dianalisis dari segi temuan tata bahasa. Pada tahap deskripsi, teori trasitivitas Halliday digunakan sebagai pijakan teori dalam menganalisis klausa. Tahap interpretasi berkaitan dengan proses penafsiran teks kutipan pernyataan Polri yang dikaitkan dengan tindakan praktik wacana. Tahap terakhir, tahapan eksplanasi bertujuan untuk mencari simpulan atas penafsiran yang didapat dari tahap interpretasi. Hal itu tersebut juga diterapkan untuk menyimpulkan mengapa pernyataan langsung Polri tersebut di produksi. Di sisi lain, terdapat metode analisis isi yakni abduktif inferensi juga disertakan guna menguak kemungkinan adanya upaya hegemoni dalam fenomena tersebut. Krippendorf (2004: 36), mendefiniskan metode abdukti inferensi merupakan metode analisis yang digunakan dengan cara menarik kesimpulan antar teks yang telah dihubungkan. Hal tersebut diterapkan dalam menganalisis kutipan pernyataanpernyataan Polri untuk menjawab permasalahan penelitian.

\section{HASIL DAN PEMBAHASAN Hasil}

Teks yang dimuat media mampu untuk mengkonstruksikan sebuah realitas sosial. Analisis teks berdasaran analisis wacana kritis Fairclough dapat mengungkap maksud yang tersembunyi dari sebuah teks (Hasanah dan Mardikantoro, 2017).
Pernyataan langsung kepolisian mengenai kasus penyiraman air keras terhadap Novel Baswedan dapat menggambarkan sebuah realitas peristiwa itu. Penggunaan tata bahasa dalam pernyataan langsung menjadi alat untuk mengungkap maksud yang dikehendaki.

Muhajir (2018), pilihan kosakata, tata bahasa, dan struktur teks dalam wacana dapat merepresentasikan ide, pengalaman manusia, dan nilai ideologis. Ide, pengalaman manusia, dan nilai ideologis yang direpresentasikan oleh suatu bentuk sistem transitivitas dapat menyimpulakan suatu hal. Serupa dengan Wiratno (2018), bahwa klausa berperan sebagai sarana aktualisasi pola pengalaman pengguna bahasa terhadap peristiwa disekitarnya. Pola pengalaman tersebut direpresentasikan dalam bentuk proses material, proses verbal, proses mental, proses behavioral, dan poses relasional. Hal itu berdasar pada pemikiran Halliday dan Mathiessen (2004), bahwa transiitivitas dapat menunjukkan adanya makna representasi di dalam klausa, berupa proses yang berkaitan dengan sirkumstan dan partisipan.

Temuan pertama, Pernyataan langsung kepolisian dianalisis menggunakan sistem transitivitas guna mengetahui makna yang direpresentasikan melalui penggunaan klausa. Klausa-klausa yang diidentifikasi berdasarkan temuan tipe proses dapat menyiratkan sebuah makna tentang kinerja Polri dalam kasus peneroran Novel Baswedan. Penjelasan terperinci akan dipaparkan di pembahasan berikut. Temuan total 74 klausa dari 42 kutipan pernyataan kepolisian teridentifikasi tipe-tipe proses, sebagai berikut: 
Tabel 1. Representasi Kinerja Polri berdasarkan Analisis Transitivitas

\begin{tabular}{cclc}
\hline No & \multicolumn{1}{c}{ Representasi Kinerja } & \multicolumn{1}{c}{ Proses } & Persentase \\
\hline 1. & Bentuk tanggung jawab kepolisian & Proses Material & $39 \%$ \\
2. & Bentuk kredibilitas dari kepolisian & Proses Mental & $30 \%$ \\
& & Proses Verbal & $14 \%$ \\
\multirow{2}{*}{ 3. } & \multirow{2}{*}{ Bentuk kooperatif dari kepolisian } & Proses Relasional & $9 \%$ \\
& & Proses behavioral & $4 \%$ \\
\hline
\end{tabular}

Bentuk-bentuk kinerja kepolisian dalam penanganan kasus penyerangan Novel disimpulkan dari temuan klausaklausa. Temuan klausa yang terindentifikasi ke dalam tipe proses merupakan representasi dari ekspresi pengalaman kepolisian terkait proses penyelidikan kasus tersebut. Interpretasi tersebut tidak sebatas dari proses, tetapi juga penghubungkan proses dengan keberadaan sirkumstan dan partisipan. Temuan partisipan aktor dalam data mendominasi kemunculan sebanyak 30 kali (27\%). Disusul dengan partisipan peran senser 21 kali (19\%) dan partisipan goal 16 kali ( 14\%). Sementara peran partisipan yang mucul di bawah persentase $10 \%$. Dan untuk dominasi sirkumstan dengan frekuensi kemunculan tertinggi ialah sirkumstan masalah (matter) 23 kali ( 46\%), kemudian disusul sirkumstan cara (manner) dengan frekuensi kemunculan 19 kali (27,5\%). Sementara jenis sirkumstan lain, meliputi sirkumstan lokasi (location), sirkumstan rentang (extent), sirkumstan penyerta (accompaniment), sirkumstan lingkungan (contingency), sirkustan pandangan (angel) memiliki frekuensi kemunculan di bawah
10\%. Temuan entitas yang memiliki peran sebagi proses, partisipan, dan sirkumstan dianalisis berkesinambungan untuk mendapatkan 'suatu hal' yang tersirat dalam wacana tersebut. Hal tersebut sejalan dengan penelitian Fauzan (2015), mengenai penggunaan transitivitas guna mengetahuirepresentasi TV One dalam memberitakan kasus lumpur lapindo.

Temuan kedua, kinerja Polri yang direpresentasikan oleh penggunaan bahasa dapat menyiratkan adanya sebuah dominasi. Temuan dari reprepsentasi kinerja kepolisian dapat menjadi alat untuk menghegemoni pihak lain. Pernyataan langsung kepolisian dapat memiliki fungsi tersirat selain untuk memberikan informasi dan klarifikasi. Senada dengan pimikiran Siregar, dan Else (2019), bahwa pemilihan kosa kata dapat mengkonstruksikan sebuah bentuk atau upaya hegemoni. Wacana yang diproduksi oleh kepolisan tentang kasus peneroran terhadap Novel Baswedan berpotensi memiliki kekuatan dalam menghegemoni masyarakat, sebagai berikut ini. 


\section{PEMBAHASAN}

\section{Representasi Kinerja Kepolisian}

Pernyataan langsung Polri yang termuat dalam 18 artikel berita di media kompas.com menyiratkan beberapa bentuk kinerja dari kepolisian. Bentuk kinerja Polri terepresentasikan oleh penggunaan dari klausa-klausa. Klausa dipandang sebagai unsur linguistik yang menjadi sumber makna untuk merepresetasikan sebuah pengalaman. Hal itu diutarakan juga oleh Wiratno (2018:91), bahwa klausa dalam makna ideasional sebagai sarana aktualisasi pengalamam dari pengguna bahasa terhadap peristiwa di sekitarnya. Pola pengalaman tersebut direpresentasikan klausa-klausa yang terklasifikasi ke dalam beberapa tipe proses. Halliday dan Matthiessen (2004), menjelaskan bahwa proses merupakan suatu entitas yang merujuk pada suatu kegiatan atau aktifitas dalam sebuah klausa. Dimana peran partisipan sebagai orang atau benda dalam proses dan sirkumstan sebagai lingkungan terjadi proses yang melibatkan partisipan. Hal itu senada dengan kajian Usman (2015), makna atau nilai yang terkandung dalam teks wacana dapat teridentifikasi melalui analisis proses, partisipan, dan sirkumstan yang saling terhubung.Pandangan tersebut menjadi dasar dalam mengakaji representasi kinerja. Berdasarkan analisis, menunjukkan bahwa temuan klausa dari penyataan langsung kepolisian yang merepresentasikan kinerja kepolisian terbagi ke dalam beberapa proses, yakni proses material, proses mental, proses verbal, proses behavioral, dan proses relasional. Berikut ini temuan bentuk kenerja kepolisian yang terepresentasi melalui temuan klausa dalam pernyataan langsung mereka.

\section{Bentuk Tanggung Jawab Kepolisian}

Kinerja Polri dalam menyelesaikan kasus penyerangan air keras Novel Baswedan yang direpresentasikan klausaklausa proses material adalah bentuk tanggung jawab Polri. Proses material merupakan proses yang menunjukkan perbuatan yang dilakukan atau peristiwa terjadi. Dan juga proses material bersifat konkret yang mengindikasikan aktivitas fisik (Halliday dan Matthiessen, 2004). Pernyataan langsung Polri dalam data penelitian ditemukan adanya proses material dengan persentase 39\% dari klausa yang berjumlah 29 klausa proses material. Klausa-klausa yang teridentifikasi sebagai proses material dapat disimpulkan merepresentasikan bentuk tanggung jawab kepolisian dalam kasus itu. Representasi itu diperoleh dengan menarik garis merah dari temuan klausa-klausa proses material, kemudian dihubungkan dengan partisipan dan sirkumstan femonema kebahasaan tersebut. Hal itu senada dengan tulisan Liao dan Geling (2019), dalam mengidentifikasi perbedaan ideologi dalam teks pidato pelantikan Presiden Trump dan Presiden Xi Jinping. Proses material memperlihatkan hal-hal atau tindakan konkret yang telah dilakukan oleh kepolisian. Berikut ini temuan beberapa bentuk lingual yang merepresentasikan proses material. 
Tabel 2. Temuan Proses Material

\begin{tabular}{|c|c|c|c|}
\hline No & Actor & Process: material & Goal \\
\hline 1. & Kita & $\begin{array}{l}\text { Tuangkan } \\
\text { ambil, tangkap, kerja } \\
\text { ada kerja sama }\end{array}$ & $\begin{array}{l}\text { pelaku } \\
\text { daftar pertanyaan, } \\
\text { pengungkapan kasus itu } \\
\text { dalam berita acara }\end{array}$ \\
\hline 2. & Kami & $\begin{array}{l}\text { tinggal tambah, kerja, bekerja } \\
\text { mempersiapkan, koordinasi } \\
\text { tetap melibatkan, sudah meminta } \\
\text { Mendapatkan } \\
\text { sudah mengamankan }\end{array}$ & $\begin{array}{l}\text { beberapa penyidik } \\
\text { anggota } \\
\text { KPK } \\
\text { support } \\
\text { dua pelaku }\end{array}$ \\
\hline 3. & tim penyidik & terus bekerja, datang & melakukan penyidikan \\
\hline 4. & Saya & Membentuk & satuan tugas \\
\hline 5. & Dia (Polda) & Menangani & kasus \\
\hline 6. & Novel & berikan, menuding & informasi \\
\hline 7. & (kamu) & sini kasih & ke saya (kepolisian) \\
\hline 8. & Polisi & tetap melakukan & penyidikan \\
\hline 9. & Kapolri & sudah mengeluarkan & surat perintah \\
\hline
\end{tabular}

Tabel 2 menunjukan temuan bentukbentuk proses material dalam klausa di data pernyataan Polri. Temuan klausaklausa proses material secara keseluruhan merujuk pada tindakan-tindakan konkret yang telah dilakukan oleh instansi kepolisian. Tindakan konkret yang direpresentasikan lewat proses material dapat mengindikasikan adanya bentuk tanggungjawab dari kepolisian. Interpetasi bentuk tanggung jawab Polri diperoleh karena terdapat tindakan konkret yang berujung pada sebuah tujuan yang nyata daritindakan-tindakan tersebut. Partisipan dari hal-hal yang dirujuk proses material ialah kepolisian, dengan representasi penggunaan kata ganti. Beberapa interpretasi dari sampel data bentuk proses material dijabarkan sebagai berikut.

(1) Saya membentuk satuan tugas khusus untuk penanganan kasus Novel ini dengan 166 penyidik (Ed. 14/3/18)
Kalimat tersebut penggunaan klausa yang mengidentifikasikan sebagai proses material. Klausa 'saya membentuk satuan tugas khusus' terdapat proses material dengan penjebaran, 'saya [partisipan] membentuk [proses material] satuan tugas khusus [goal] untuk penanganan kasus Novel ini dengan 166 penyidik sirkumstan]. Penjebaran unsurunsur tersebut dapat menunjukkan peran nyata partisipan 'saya' dalam melakukan suatu langkah penyelidikan konkret. Langkah penyelidikan konkret direpresentasikan oleh verba 'membentuk' sebagai penanda proses material. Verba 'membentuk' menginterpretasikan sebuah aktifitas nyata yang teah dilakukan dengan tujuan tertentu. Tujuan yang hendak dicapai dari tindakan itu ialah 'satuan tugas khusus'. Klausa dengan partisipan pronomina 'saya' itu dapat menjadi salah satu penanda bentuk perwujudan 
pertanggungjawaban Polri terhadap proses hukum yang sedang berlangsung.

Bentuk proses material lain yang merepresentasikan pertanggungjawaban kepolisian berikut ini:

(2) Kami sudah mengamankan dua pelaku RM dan RB (Ed. 27/12/19).

Kalimat sampel data 2 memiliki penjabaran unsur meliputi, 'kami [patisipan] sudah mengamankan [proses material] dua pelaku RM dan RB [goal]' Klausa tersebut memiliki partisipan pronomina jamak 'kami' yang merujuk pada instansi kepolisian lebih spesifiknya para tim penyidik kasus Novel. Suatu tindakan konkret yang telah dilakukan partisipan direpresentasikan oleh verba 'sudah mengamankan'. Penggunaan verba 'sudah mengamankan' memberikan gambaran tindakan pengamanan atau penangkapan yang dilakukan oleh penyidik kepolisian. Tindakan tersebut menghasilkan tujuan yang telah tercapai yakni 'dua pelaku RM dan RB' [goal]. Representasi bentuk proses material 'sudah mengamankan' dapat diinterpretasikan telah dilakukannya langkahlangkah tertentu dalam proses penyelidikan hingga berhasil menangkap atau mengamankan terduga pelaku. Klausa tersebut dapat merepresentasikan bentuk pertangungjawaban dari pihak kepolisian yang dapat menentukan kinerja instansi terkait.

Proses material pada tabel 2 ditandai dengan penggunaan verba meliputi 'tidak mungkin ambil', 'sudah memberikan', 'udah upayakan', 'tuangkan', 'ambil', 'tangkap', 'kerja', 'tinggal tambah', 'mempersiapkan', 'koordiasi', 'tetap melibatkan', 'sudah meminta pendapat', 'terus bekerja', 'datang', 'sudah melangkah', 'membentuk', 'menangani', 'berikan', 'menuding', 'sini kasih', 'tetap melakukan'. Bentuk-bentuk yang merepresentasikan proses material tersebut menunjukkan tindakan yang bersifat aktif dari partisipan. Tindakan-tindakan tersebut berjenis tindakan konkret yang melibatkan aktivitas fisik. Interpretasi tersebut juga diasarkan pada padangan (Gerot \& Wignel, 1995), bahwa proses material mengekspresikan suatu ha yang diakukan oleh entitas fisik. Berdasarkan penelitian, tindakan-tindakan kepolisian yang terepresentasi dalam proses material merupakan tindakan yang melibatkan aktivitas fisik. Tindakan konkret yang dilakukan memiliki tujuan nyata berkaitan dengan kasus penyerangan Novel. Oleh karena itu, tindakan dalam proses material tersebut dapat menunjukkan bentuk pertanggungjawaban pihak kepolisian. Pernyataan langsung kepolisian dalam data yang teridentifiaksi terdapat $39 \%$ proses material dapat direpresetasikan adanya upaya pemertegas kinerja kepolisan. Dari penggunaan proses material tersebut, publik dapat memiliki pandangan bahwa instansi kepolisian dapat diinterpretasi sebagai lembaga dengan karakteristik yang bertanggungjawab. Pernyataan langsung kepolisian yang menyiratkan langkahlangkah investigasi dan hasil yang telah diperoleh dapat menjadi penguat interpretasi kinerja tersebut. Dominasi penggunaan klausa proses material guna mereprentasikan peristiwa, tindakan, atau aktifitas dari partisipan dapat dirujuk pada Yuliana, dkk (2018). 


\section{Bentuk kredibilitas Kepolisian}

Kredibilitias berkaitan dengan tingkat kepercayaan terhadap individu atau kelompok tentang suatu hal. Rasa kepercayaan terebut yang coba dibangun oleh kepolsian melalui pernyataan langsung mereka. Beberapa temuan klausa dalam pernyataan langsung kepolisian teridentifikasi sebagai klausa proses mental dan proses verbal. Bentuk proses mental berkaitan dengan tindakan yang melibatkan unsur kognisi, afeksi, keinginan, dan persepsi mengenai kasus penyerangan air keras. Proses mental dalam data teridentifikasi sebanyak 22 klausa dengan persentase 30\%. Selain proses mental, proses verbal dalam data pernyataan langsung juga dapat merepresentasikan kepercayaan dari kepolisian. Temuan bentuk kredibilitas kepolisan sebagai representasi kinerja Polri dikarena transitivitas sebagai suatu bagian tata bahasa dapat mengidentifikasi sebuah representasi.

Proses mental di dalam sebuah wacana tidak terlepas dari unsur proses merasakan (sensing). Proses 'perspektif' merasakan tersebut melibatkan indera pendengar, penglihat penciuman, pengecap, dan peraba Alvionita (2018). Berikut ini temuan klausa proses mental dalam data melibatkan memiliki bentuk lingual yang mereprsentasikan proses, sebagai berikut.

Data Tabel 3 menunjukan temuan beberapa bentuk proses mental dari pernyataan langsung kepolisian. Keselurahan data tabel 3 menggunakan pronomina pertama dan ketiga. Pronomina persona tunggal meliputi 'saya' dan pronomina persona jamak yakni 'kita' dan 'kami'. Pronomina ketiga jamak yaitu 'tim'. Pronomina-pronomina tersebut merepresentasikan kepolisian sebagai unsur senser dalam proses mental tersebut. Senser menjadi pihak yang melakukan tindakan dalam proses mental terkait proses investigasi kasus air keras.

Data proses mental akan dijabarkan beberapa berikut ini mengenai peran senser dan interpretasi yang tersirat.

(3) Kita akan lakukan penyidikan kalau itu sudah fakta hukum dan ada alat buktinya (Ed. 1/8/2017)

Tabel 3. Temuan Proses Mental

\begin{tabular}{|c|c|c|c|}
\hline No & Senser & Process: mental & Phenomenon \\
\hline \multirow[t]{5}{*}{1.} & Kita & $\begin{array}{l}\text { akan lakukan,akan selidiki } \\
\text { akan teruskan }\end{array}$ & penyidikan \\
\hline & & $\mathrm{mau}, \mathrm{mau}$ & periksa,bagus, bersih \\
\hline & & coba nanti & \\
\hline & & tidak main-main & \\
\hline & & jangan menanggap & yang lambat atau menghabat \\
\hline 2. & Kami & dalami, akan berangkat, menyakini & keterangan, pelaku akan tertangkap \\
\hline 3. & Tim & bisa, akan melakukan & kerja sama,analisis TKP \\
\hline 4. & Saya & $\begin{array}{l}\text { ingin meyakinkan } \\
\text { akan ungkap }\end{array}$ & penyidik terus bekerja maksimal \\
\hline 5. & Kepolisian & telah mempuyai & penyelesaian $60 \%$ \\
\hline
\end{tabular}


Kalimat 3 menyiratkan proses mental dengan ditandai 'akan melakukan' yang diucapkan oleh senser, 'kita'. Hal yang ditandai oleh senser yaitu 'penyidikan' sebagai phenomenon dan dijelaskan lebih lanjut oleh sirkumstan 'kalau itu ada fakta hukum dan ada alat buktinya'. Pronomina persona pertama jamak 'kita' merepsresentasiskan tim penyidik kepolisian yang memiliki langkah-langkah hukum. Klausa proses mental 'kita kaan melakukan penyidikikan' menyiratkan adanya sebuah langkah hukum yang akan dan dapat ditempuh oleh kepolisian. Langkah hukum melakukan penyelidikan dapat dilaksanakan jika suatu hal dipenuhi, yang direpresentasikan dalam sirkumstan.

Klausa dengan proses mental tersebut dapat memberikan rasa percaya dan yakin untuk publikbahwa dapat terselesaikannya kasus penyerangan Novel.

Berdasarkan data Tabel 3 secara dominan menyiratkan adanya upaya untuk menyakinkan publik tentang usaha kepolisian dalam menyelesaikan kasus Novel. Upaya tersebut direpresentasikan oleh verba-verba penanda proses mental. Selain itu, upaya membangun kepercayaan masyarakat diperkuat dari penggunaan modal 'akan'. Menurut (Alwi,
1992), pemarkah 'akan' berjenis modal intensional yang menyatakan makna 'keakanan' terhadap suatu hal. Di dalam klausa, modal tersebut dapat diinterpretasikan adanya sebuah keinginan atau tindakan yang hendak dicapai atau dilaksanakan oleh kepolisian untuk memproses kasus tersebut. Jika dilihat dari segi aspektualitas pemarkah modal 'akan' bermakna adanya proses yang belum terselesaikan dan memiliki tujuan akhir pasti. Akan tetapi, dalam upaya mencapai tujuan tersebut, partisipan sudah melakukan langkah tertentu. Hal itu, selaras dengan penggunaan pemarkah 'akan lakukan', 'akan selidiki', dan 'akan teruskan' dalam data yang menyiratkan ada sebuah tindakan yang akan dilakuan kepolisian.

Temuan bentuk proses lain dalam data yang mendukung adanya bentuk kredibilitas Polri dalam kinerjanya yakni proses verbal. Kusumawardani dan I Ketut (2020) dalam temuannya, menjelaskan bahwa proses ini dapat menunjukkan aktivitas mengenai komunikasi antarpelibat dalam lingkup komunikasi verbal. Proses veral yang ditemukan memiliki pemarkah sebagai berikut.

Tabel 4. Temuan Representasi Proses Verbal

\begin{tabular}{llll}
\hline No & Sayer & Process: verbal & Verbiage \\
\hline 1. & Saya & tanya, bilang, sampaikan & $\begin{array}{l}\text { tugas pokok dan fungsi, kami optimis } \\
\text { bisa terungkap, kasus itu ada } \\
\text { karekateristiknya masing-masing. } \\
\text { tidak semua peristiwa bisa dapat } \\
\text { dengan cepat }\end{array}$ \\
2. & Kita & sudah bilang & \\
3. & Penyidik & menanyakan & \\
4. & keterangan Novel & disampaikan & \\
\hline
\end{tabular}

Representasi Hegemoni Kinerja Polri dalam Pemberitaan Teror Air Keras Novel Baswedan... 
Temuan proses verbal dapat menjadi salah satu bukti kredibilitas yang dimiliki kepolisian. Proses verbal memperlihatkan tindakan yang dilakukan Polri, berupa pemberian penjelasan mengenai keadaan terbaru dan tindakan yang telah dilakukan. Bentuk proses verbal dalam klausa memberikan interpretasi bahwa dengan kewenangannya kepolisian optimis menyelesaikan kasus ini. Hal itu dapat diperjelas dari penjabaran data berikut ini.

\section{(4) Saya bilang kan beberapa kali kami optimis bisa terungka $p$ (Ed. 12/4/18)}

Data 4 mengandung unsur proses verbal yaitu 'saya [sayer] bilang [proses verbal] kan beberapa kali [sirkusmtan] kami optimis bisa terungkap [verbiage]. Dari penjabaran tersebut terlihat bahwa kepolisan mewartakan rasa optimis mereka bisa mengungkap kasus ini. Hal itu menyiratkan adanya hal-hal yang telah dan bisa dilakukan oleh kepolisian terkait kasus Novel. Dan juga, penggunaan sirkumstan 'kan beberapa kali' menunjukkan pengulangan dan informasi konsisten yang diberikan. Oleh sebab itu, proses verbal dapat diinterpretasikan salah satu bentuk kredibilitas yang dimiliki kepolisian
Berdasarkan temuan proses verbal, secara keseluruhan pemarkah proses verbal dengan jelas menyiratkan keadaan, tindakan, dan rencana kepolisiann. Penggunaan pemarkah proses verbal dapat memberikan interpretasi bahwa kepolisan memiliki rencana dan strategi dalam mengungap kasus tersebut. Dan, hal itu dapat membangun rasa kepercayaan publik terhadap instansi kepolisian. Temuan bentuk kredibilitas yang dimiliki kepolisian didapatkan dari analisis berkesinambungan klausa-klausa proses mental dan proses verbal dengan partisipan dan sirkumstan yang menyertai.

\section{Bentuk Kooperatif Kepolisian}

Kooperatif dalam kinerja kepolisian berkaitan upaya melibatkan pihak-pihak lain guna menyelesaikan kasus. Tindakan kepolisian dalam proses hukum kasus ini melibatkan pihak lain, seperti saksi. Hal itu berkaitan juga dengan sikap profesionalitas yang miliki oleh kepolisian. Bentuk sikap profesionalitas dan kooperatif Polri terepresentasi dari penggunaan pemarkah proses relasional dan behavioral. Proses relasional ditemukan dalam data sebesar $13 \%$ dengan total klausa 9, sedangkan proses behavioral sebesar $5 \%$ dengan 4 klasua. Bentuk-bentuk reprsentasi dari proses relasional terbagi menjadi proses relasional atributif dan proses relasional identifikatif disajikan pada Tabel 5.

Tabel 5. Temuan Proses Relasional

\begin{tabular}{|c|c|c|c|}
\hline \multicolumn{4}{|c|}{ Proses Relasional Atributif } \\
\hline No & Carrier & Process relational & Attribute \\
\hline 1. & Kami semua & adalah & transaparan,maksimal soal itu \\
\hline 2. & Kita & adalah & profesional \\
\hline \multicolumn{4}{|c|}{ Proses Relasional Identifikatif } \\
\hline No & Identified & Process relational & Identifier \\
\hline 1. & Semua orang & punya & hak yang sama \\
\hline 2. & Kami & memiliki & kepentingan \\
\hline
\end{tabular}


Dari temuan bentuk proses relasional atributif terdapat satu pemarkah sama yaitu 'adalah' dengan carrier 'kami semua' dan 'kita'. Proses relasional atributif menunjukkan adanya hubungan yang dimiliki penyandang dengan apa yang disandangkan (Wiratno, 2018). Pada temua data penyandang (carrier) merepresentasikan kepolisian dan hal yang disandangkan berupa sikap transparan, maksimal, dan profesionalitas. Perihal yang disandangkan menunjukkan sifat dan tindakan yang diterapkan dalam proses pengungkapan kasus teror air keras kepada Novel.

Proses relasional identifikatif yang ditemukan juga menujukkan adanya profesionalitas yang dimiliki oleh kepolisian. Bentuk proses relasional tersebut mencirikan perihal yang dimiliki oleh partisipan. Berdasarkan data kepolisian memberi perlakuan sama dihadapan hukum. Hal itu ditunjukkan dalam penggunaam proses relasional identifikatif pada klausa berikut.

(5) Semua orang punya hak yang sama (Ed. 6/11/17)

Klausa tersebut kutipan dari salah satu pernyataan langsung kepolisian yang menyatakan semua orang memiliki hak yang sama dalam memperjuangkan kebenaran. Hal yang diidentifikasikan ialah 'hak yang sama'. Penggunan proses relasional dapat diinterpretasikan adanya perlakuan sama terhadap kasus penyerangan air keras. Kepolisian menyiratkan bahwa penyidik KPK, Novel Baswedan memiliki hak sama dalam mencari kebenaran dari penyerangan tersebut. Hal itu serupa temuan Chen (2018), bahwa proses relasional dapat menggambarkan suatu keadaan yang mengandung unsur permanen, objektif, dan wibawa.

Bentuk sikap kooperatif dalam penyelidikan kasus penyerangan itu tercermin juga dari penggunaan pemarkah prosoes behavioral. Pemarkah proses behavioral yang ditemukan disajikan pada Tabel 6 .

Pada Tabel 6 terdapat bentuk proses behavioral meliputi 'melihat', 'menyentuh', 'doakan', dan 'tidak menyentuh'. Bentuk-bentuk tersebut merepresntasikan pihak kepolisian, saksi, dan Tim Gabungan Pencari Fakta. Penggunaan proses behavioral mencerminkan keadaan yang dapat dilakukan oleh kepolisian. Seperti pada penggunan proses behavioral 'menyentuh' dengan partisipan 'kami', kepolisian. Hal itu merepresentasikan keadaan bahwa pihak kepolisian dapat melakukan langkah dan strategi tertentu guna investigasi kasus penyerangan terhadap Novel.

Tabel 6. Representasi Proses Behavioral

\begin{tabular}{llll}
\hline No & Behaver & Process & \\
\hline 1. & Saksi & melihat & Penyerangan \\
2. & Kami & menyentuh, doakan & $\begin{array}{l}\text { hal-hal teknis, semakin hebat dan semakin } \\
\text { banyak memberikan keterangan } \\
\text { hal-hal teknis }\end{array}$ \\
3. & TGPF & tidak menyentuh & hal
\end{tabular}

Representasi Hegemoni Kinerja Polri dalam Pemberitaan Teror Air Keras Novel Baswedan... 
Penjabaran hasil temuan di atas menunjukkan bahwa sistem transitivitas dapat merepresentasikan bentuk-bentuk dari kinerja kepolisian. Proses dapat merepresentasikan hal, tindakan, keadaan, dan rencana yang dilakukan atau berhubungan dengan kepolisian. Representasi tersebut dapat memunculkan interpretasi di masyarakat terkait kinerja kepolisian dalam kasus Novel. Oleh sebab itu, meskipun proses pengungkapan kasus teror masih berjalan, tetapi lewat penggunaan unsur leksikogramatikal dalam wacana yang dibangun, masyarakat sudah dapat memiliki pandangan bagaimana bentuk kinerjanya.

\section{Upaya Hegemoni Kepolisian}

Pernyataan-pernyataan yang dikeluarkan oleh kepolisian tidak sebatas memberikan klarifikasi dan informasi terbaru kepada publik. Kepolisan melalui pernyataan di media, salah satunya kompas.com, dapat memberikan hegemoni atau dominasi kepada publik. Temuan hasil penelitian tersebut juga selaras dengan penelitian (Abadi et al. 2017) bahwa ada fungsi lain dari wacana yang diproduksi oleh pihak atau kelompok yang memiliki kekuatan. Akan tetapi, identifikasi unsur hegemoni dalam pernyataan langsung kepolisian ini melibatkan transitivitas guna mengkaji temuan unsur leksikogramatikal. Hasil temuan menunjukkan, bahwa upaya hegomoni dapat dilakukan karena dalam konteks kasus ini, kepolisian memiliki kekuatan dan kewenangan dalam memproses hukum. Kewenangan Polri sebagai lembaga hukum yang memiliki sarana dan prasarana penunjang proses hukum memberikan kekuatan lebih bagi Polri.

Interpretasi adanya unsur hegemoni dalam wacana yang dibangun kepolisian dilatarbelakangi sebab tertentu. Interpretasi tersebut dapat muncul dari kinerja yang ingin ditunjukkan kehadapan pulik. Proses hukum yang masih berjalan dan belum terungkap pelaku menjadi faktor utama. Jeda waktu yang relatif panjang, hampir 3 tahun, memunculkan beberapa keraguan di publik. Keraguan tersebut muncul dari beberapa pihak, seperti yang dikutip dalam pemberitaan media online merdeka. com edisi 1 November 2017 dan detik.com 3 Januari 2018. Pemberitaan merdeka.com berisi tentang usulan pembentukan TGPF yang diutarakan oleh Fadli Zon. Detik.com saat itu memberitakan dari pernyataan Danhil Anzar, Ketua Pemuda Muhammadiya, mengenai rasa kurang optimis bahwa kasus ini dapat terselesaikan. Keraguan yang muncul tersebut dapat dilatarbelakangi banyak faktor, salah satunya sejarah ketegangan yang pernah terjadi antara KPK dan Polri.

Kinerja kepolisian yang direpresentasikan dalam pernyataan langsung dapat menjadi alat untuk menghegemoni. Temuan-temuan bentuk kinerja kepolisian berupa bentuk tanggungjawab, kredibilitas, dan profesionalitas kepolisian dapat menyangkal asumsi-asumsi negatif yang muncul. Hal itu disebabkan karena ada unsur kekuasaan yang tercipta melalui peryataan langsung kepolisian. 
Keadaan tersebut bertujuan agar individu atau kelompok tertentu mengikuti hal yang menjadi tujuan dari pihak dominan. Seperti diungkapkan Gramsci (1971), kelompok dominan akan berusaha memberikan pengaruh kepada kelompok di bawahnya. Berdasarkan analisis, pernyataan langsung kepolisian dapat memilik fungsi lain yang berdampak kepada masyarakat,yaitu wacana berfungsi untuk meyakinkan masyarakat, wacana berfungsi untuk mempengaruhi masyarakat, dan wacana untuk mengontrol atau mengatur masyarakat.

Wacana kepolisian dapat menyiratkan fungsi untuk meyakinkan masyarakat, selaian memberikan informasi terbaru. Usaha menyakinkan masyarakat terlihat dari penggunaan leksikogramatikal yang digunakan. Pemaparan mengenai tindakan-tindakan yang telah dilakukan oleh kepolisian dapat meyakinkan publik. Temuan penggunaan modal juga dapat memperkuat upaya untuk meyakinkan pihak lain. Publik dapat merasa yakin bahwa telah ada usaha nyata dan strategi yang akan dilaksanakan dari kepolisian untuk mengungkap kasus tersebut. Meskipun, dalam kenyataannya publik dihadapakan bahwa kasus penyerangan air keras terhadap Novel belum terselesaikan. Data pernyatan langsung yang merepresetasikan kinerja kepolisian juga dapat menyakinkan publik tentang adanya progres dari proses hukum tersebut.

Fungsi dari data pernyataan langsung kepolisian selain menyangkal persepsi ketidakoptimisan kepolisian, dapat juga untuk mempengaruhi masyarakat.
Masyarakat telah menerima berbagai pemberitaan penyerangan Novel Baswedan dari berbagai sudut pandang. Dari hasil analsis, bentuk kinerja kepolisian yang terepresentasikan dapat berfungsi untuk mempengaruhi masyarakat akan kesungguhan kepolisian. Masyarakat dapat melakukan dan berpersepsi seperti yang diinginkan. Hasil analisis kinerja kepolisian itu dapat mempengaruhi masyarakat untuk tetap percaya dan merasa yakin bahwa kepolisian akan menyelesaikan tanggungjawabnya secara tuntas. Kewenangan yang dimiliki kepolisian menciptakan adanya upaya hegemoni lewat wacana tersebut.

Kepolisian sebagai penegak hukum yang legal dapat memberikan perintah terhadap hal-hal yang bersangkutan dalam proses hukum. Upaya untuk mengatur juga menjadai salah satu bentuk hegemoni dalam pernyataan langsung kepolisian. Hal itu tersirat dalam penggunaan leksikogramatikal keposian yang menyatakan agar kesaksisan Novel hendaknya diberikan kepada kepolsian, 'Supaya penyidik Polda Metro Jayabisamenidaklanjutinya, informasiinformasi yang dianggap pentinng oleh saudara Novel, hendaknya disampaikan kepada penyidik (Ed. 15/6/17)'. Kutipan data tersebut, dapat diinterpretasikan sebagai salah satu bentuk mengontrol dan mengatur dari kepolisian. Kepolisian berwenang terhadap proses penyelidikan kasus ini, sehingga kesaksian Novel mengenai tidak seharusnya diberikan kepada pihak lain. Dari hasil analsis data ditemukan juga upaya untuk mengontrol 
agar informasi yang beredar di masyarakat tidak beredar tanpa pertanggungjawaban.

Merujuk pada tahapan analsisi wacana kritis Fairclough (1995) keberadan hegemoni dalam sebuah wacna dapat dijabarkan dalam tahap interpretasi dan eksplanasi. Berdasarkan pernyataan-pernyataan langsung kepolisian dalam data, secara keseluruhan dapat disimpulkan mengandung unsur citra positif bagi kepolisian. Representasi dari kinerja kepolisian menunjukkan hal-hal positif mengenai kepolisian di tengah isu proses hukum kasus Novel Baswedan. Representasi bentuk kinerja kepolisian itu dapat menjadi alat untuk menghegemoni publik melalui wacananya. Situasi tersebut, dapat mempertahankan persepsi kepolisian sebagai lembaga penegak hukum yang memiliki kredilitas, profesional, dan bertanggungjawab. Unsur keberadaaan media juga memberi pengaruh yang besar dalam upaya hegemoni tersebut. Media online kompas. com masuk 4 besar media dengan jumlah pembaca dan kunjungan situs terbanyak menurut survei cumsocre pada akhir 2017. Penyataan langsung kepolisian dalam pemberitaan kompas.com juga beberapa kali menjadi topik pemberitaan utama. Oleh karena itu, keberadana media dalam memberitakan memberikan pengaruh secara tidak langsung pada upaya hegemoni tersebut.

\section{SIMPULAN}

Penyataan langsung kepolisian yang merupakan salah satu bentuk wacana yang memiliki tujuan pembuatan. Berdasarkan analisis, dapat ditarik simpulan bahwa pemilihan kata dapat menyiratkan pengalaman, aktivitas, dan peristiwa yang melibatkan penutur. Hal tersebut dapat diketahui dari analisis transitivitas guna melihat hal yang direpresentasikan di dalam klausa. Fenomena tersebut ditemukan di dalam penelitian, bahwa klausa-klausa dalam pernyataan langsung kepolisian merepresntaikan beberapa hal terkait kinejra kepolisian meliputi, 1) 1) bentuk tanggungjawab kepolisian, 2) kredibilitas kepolisian, dan 3) profesionalitas dan kooperatif kepolisian dalam menangani kasus penyerangan Novel.

Temuan lain yakni penggunaan bahasa olah pihak tertentu dalam sebuah wacana dapat menghadirkan unsur hegemoni. Bahasa dapat menghegemoni suatu kelompok jika diproduksi oleh pihak yang memiliki kekuatan dan kekuasaan. Hal tersebut ditemukan dalam anaslisi, bahwa pernyataan yang diproduski kepolisian memiliki upaya hegemoni kepada publik. Upaya hegemoni yang ditemukan yaitu, menyakinkan publik terhadap kinerja kepolisian, mempengaruhi publik, dan mangatur serta mengontrol situasi yang berkembang di masyarakat. 


\section{UCAPAN TERIMA KASIH}

Pencapain penelitian ini terpublikasi menyertakan peranan berbagai pihak. Terima kasih disampaikan kepada Universitas Diponegoro, intansi yang menaungi dan memberikan fasilitas penelitian secara tidak langsug. Demikian halnya, ucapan terima kasih kepada Litera sebagai wadah untuk mempubikasikan artikel peneltian ini.

\section{DAFTAR PUSTAKA}

Abadi, M. I., Nurhadi, dan Basuki, I. B. (2016). Bentuk Hegemoni Kekuasaan dalam Tuturan Jokowi. Jurnal Pendidikan Humaniora, 4(4), 209-217. http://journal.um.ac.id/ index.php/jph/article/view/8204.

Alwi, H. (1992). Modalitas dalam Bahasa Indonesia. Yogyakarta: Kanisius.

Eggins, S. (1994). An Introduction to Systemic Functional Linguistics. London: Printer Publisher.

Fairclough, N. (1995). Critical Discourse Analysis: The Critical Study of Language. London and New York: Longman.

Fairclough, N. (1995). Dircourse and Social Change. UK: Polity Press.

Fairclough, N. (2001). Languange and Power (Edition 2). New York: Longman Inc.

Gee, J.P. (1999). An Introduction to Discourse Analysis, Theory and Method. London: Routledge.

Gerot, L., dan Wegnell, P. (1994). Making Sense of Functional Grammar. Sydney: Gerd Stabler.
Gramsci, A. (1971). Selections from the Prison Notebooks. New York: International Publishers.

Hasan, M. K. dan Ali, N. A. (2017). Hegemoni Ketua Partai terhadap Presiden dalam Majalah Tempo Edisi 13-19 April 2015 (Studi Analisis Wacana Kritis). Jurnal Franca: Jurnal Bahasa, Sastra, dan Pengajarannya, 5(2), 36-41. DOI: http://dx.doi.org/10.30651/ 1f.v1i2.559.

Halliday, M, dan Mathiessen, M. (2004). An Introduction to Functional Grammar. New York: Oxford University Press. Inc.

Kree, G. (1984). Linguistic and Ideological Transformations in news Reporting. Dalam Language, Image, Media (Davis H. Dan Walton, P. Eds). England: Basil Blackwell, 1984.

Krippendorff, K. (2004). Content Anaylsis An Introction to Its Methodology. UK : Sage Publication.

Moleong, L. J. 2007. Metode Penelitian Kualitatif. Bandung: Remaja Rosdakaraya.

Sharififar, M. and Rahimi, E. (2015). Critical Discourse Analysis of Political Speech: A Case Study of Obama's and Rouhan's Speech at UN. Journal Theory and Practice Language Study, 5(2), 343-349. DOI: http://dx.doi.org/10.17507/ tp1s.0502.14.

Sinaga, D. P., Kandagasari, N., dan Winarto, E. R. (2016). Critical Discurse Analysis of Jokowi's 
Speech at APEC CEO Summit 2014 by The Application of Transitivity. ISFC 43 Proceeding Learning Language, Learning, Through Language, Learning about Language Glocalising Systemic Functional Linguistics. Bandung: UPI. Sudaryanto. (2015). Metode dan Aneka Teknik Analisis Bahasa: Pengantar Penelitian Wahana Kebudayaan Secara Linguistik. Yogyakarta: Sanata Dharma University.
Wiratno, T. (2018). Pengantar Ringkas Linguistik Sistemik Fungsional. Yogyakarta: Pustaka Pelajar.

Wodak, R. (1996). Disorder of Discourse. London dan New York: Longman.

Van Dijk, T. A. (1998). Ideology: Multidiciplinary Approach. London: SAGE Publication.

www.kompas.com (diunduh dalam rentang waktu Mei 2017 - Des 2019). 